Jurnal Kesmas Asclepius

Volume 1, Nomor 1, Juni 2019

e-ISSN : 2684-8287

p-ISSN : 2656-8926

DOI: https://doi.org/10.31539/jka.v1i1.605

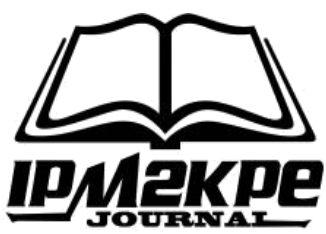

\title{
PENGARUH PENDIDIKAN KESEHATAN TERHADAP PENGETAHUAN, SIKAP DAN FREKUENSI KONSUMSI MAKANAN JAJANAN
}

\author{
Wulan Angraini ${ }^{1}$, Betrianita $^{2}$, Bintang Agustina Pratiwi ${ }^{3}$ \\ Riska Yanuarti $^{4}$, Pebi Fermana ${ }^{5}$ \\ Universitas Muhammadiyah Bengkulu 1,2,3,4,5 \\ wulanangraini@umb.ac.id ${ }^{1}$
}

\begin{abstract}
ABSTRAK
Penelitian ini bertujuan untuk mengetahui pengaruh pendidikan kesehatan dengan metode audio visual terhadap pengetahuan, sikap, dan frekuensi konsumsi makanan jajanan pada murid SDN 52 Kota Bengkulu tahun 2018. Jenis penelitian eksperimental prospektif dengan quasi experimental design dengan rancangan nonequivalent control group design. Hasil uji statistik didapatkan nilai p-value 0,002 untuk variabel pengetahuan, 0,225 untuk sikap dan 0,84 untuk frekuensi. Simpulan, ada perbedaan rata-rata pengetahuan sebelum dan sesudah diberikan pendidikan audio visual. Tidak ada perbedaan rata-rata sikap dan frekuensi konsumsi jajanan sebelum dan setelah diberikan pendidikan audio visual di Sekolah Dasar Negeri 52 Kota Bengkulu.
\end{abstract}

Kata Kunci: Frekuensi Jajanan, Pendidikan Kesehatan, Pengetahuan, Sikap

\section{ABSTRACT}

This study aims to determine the effect of health education with audio-visual methods on knowledge, attitudes, and frequency of consumption of street food in students of SDN 52 Kota Bengkulu in 2018. This type of prospective experimental research is Quasi Experimental Design with Nonequivalent Control Group Design. The statistical test results obtained p-value 0.002 for knowledge variables, 0.225 for attitudes and 0.84 for frequency. In conclusion, there is a difference in the average knowledge before and after being given audio-visual education. There was no difference in the average attitude and frequency of consumption of snacks before and after being given audiovisual education at 52 Elementary Schools in Bengkulu City.

Keywords: Snack Frequency, Health Education, Knowledge, Attitude

\section{PENDAHULUAN}

Anak sekolah dasar adalah masa anak berumur 6 tahun sampai 12 tahun, dimana mereka sedang dalam puncak pertumbuhan. Pada masa-masa ini lah anak berada dalam fase pertumbuhan dan perkembangan, sehingga berangsur-angsur menjadi banyak mengetahui tentang diri dan dunianya. Dalam tahap ini anak dalam kondisi peka terhadap stimulus sehingga mudah untuk dibimbing, diarahkan dan ditanamkan kebiasaan yang baik (Safriana, 2012). 
Makanan jajanan adalah makanan dan minuman yang diolah oleh pengrajin makanan di tempat penjualan dan atau disajikan sebagai makanan siap santap untuk dijual bagi umum selain yang disajikan jasa boga, rumah makan/restoran, dan hotel (Yasmin \& Madanijah, 2010).

Pada periode perkembangan anak sekolah ini adalah satu tahap perkembangan ketika anak mulai menjauh dari kelompok keluarga dan mulai berpusat pada kelompok usia sebaya yang lebih luas. Salah satu yang perlu diperhatikan pada masa ini adalah kebiasaan makan anak di sekolah yang dipelajari tanpa sengaja yang tidak melalui proses pendidikan. Mereka juga mulai dapat memilih dan membeli sendiri menu makanan (Yuliastuti, 2012).

Anak-anak usia sekolah dasar umumnya setiap hari menghabiskan seperempat waktu disekolah, durasi waktu yang dihabiskan ini kemudian akan berpengaruh pada pola makan anak. Anak-anak dalam usia ini mengikuti banyak aktifitas sehingga sering melupakan waktu makan. Kebiasaan anak sekolah untuk mengkonsumsi jajanan di sekolah yang belum diketahui kandungan gizi dan kebersihannya dapat berpengaruh terhadap kesehatan dan dapat menimbulkan suatu masalah kesehatan (Amourisva, 2016).

Rendahnya tingkat keamanan Pangan Jajanan Anak Sekolah (PJAS) masih menjadi permasalahan penting. Data Pangan Jajanan Anak Sekolah yang dilakukan Badan POM RI Direktorat Inspeksi dan Sertifikasi Pangan bersama 26 Balai Besar/Balai POM di seluruh Indonesia pada tahun 2009 menunjukkan bahwa 45\% PJAS tidak memenuhi syarat karena mengandung bahan kimia berbahaya seperti formalin, boraks, rhodamin, mengandung Bahan Tambahan Pangan (BTP), seperti siklamat dan benzoat melebihi batas aman, serta akibat cemaran mikrobiologi. Hasil uji yang dilakukan Badan Pengawas Obat dan Makanan (BPOM) pada Januari-Agustus 2014 hampir sepertiga jajanan anak sekolah di 23.500 sekolah dasar dan Madrasah Ibtidaiyah di Indonesia tercemar mikroba berbahaya, juga ditemukan penggunaan bahan berbahaya dan bahan tambahan pangan yang tidak memenuhi syarat (BPOM,2014).

Salah satu indikator perilaku hidup bersih dan sehat yang harus diperhatikan pada anak sekolah adalah mengkonsumsi jajanan sehat di kantin sekolah yang dapat memberi arti dan manfaat apabila aneka makanan yang disediakan memiliki kandungan gizi tinggi, sehat dan layak dikonsumsi oleh anak sekolah untuk membentuk kualitas Sumber Daya Manusia (SDM) dan derajat kesehatan para anak didik. Hampir semua anak sekolah dasar mempunyai kebiasaan jajan. Keterampilan anak dalam memilih jajanan di sekolah merupakan faktor kritis untuk mendapatkan makanan yang sesuai kebutuhan dan memenuhi syarat kesehatan (Kristianto et al., 2013).

Aspek negatif makanan jajanan yaitu apabila dikosumsi berlebihan dapat menyebabkan kelebihan asupan energi yang dapat menyebabkan obesitas. Masalah lain pada makanan jajanan berkaitan dengan tingkat keamanan. Penyalahgunaan bahan kimia berbahaya atau penambahan bahan tambah pangan yang tidak tepat oleh produsen pangan jajanan adalah salah satu contoh tingkat rendahnya pengetahuan produsen mengenai keamanan makanan jajanan. Ketidaktahuan produsen mengenai penyalahgunaan tersebut dan praktik higiene yang masih rendah merupakan faktor utama penyebab masalah keamanan makanan jajanan (Ariandani, 2011).

Anak sekolah belum mengerti cara memilih jajanan yang sehat sehingga berakibat buruk pada kesehatannya sendiri. Anak membeli jajan menurut kesukaan mereka sendiri tanpa memikirkan bahan-bahan yang terkandung di dalamnya. Anak sekolah biasanya mempunyai lebih banyak perhatian, aktivitas di luar rumah, dan sering melupakan 
waktu makan sehingga mereka membeli jajanan di sekolah untuk sekedar mengganjal perut (Safriana, 2012).

Salah satu upaya untuk membentuk perilaku sehat yaitu dengan memberikan pendidikan kesehatan. Pendidikan kesehatan sebaiknya diberikan sedini mungkin. Usia anak yang sesuai untuk diberikan pendidikan gizi adalah anak yang berada pada periode 6 sampai 14 tahun, karena pada usia ini anak mulai matang secara seksual dan matang untuk belajar serta merupakan periode intelektual. Dari rentang usia tersebut yang paling tepat diberikan pendidikan gizi adalah usia 10 tahun karena pada usia itu anak berada dalam tahap operasional formal, yaitu mampu berpikir secara abstrak, menalar secara logis, dan menarik kesimpilan dari informasi yang tersedia (Pratiwi, 2015).

Pendidikan kesehatan terhadap anak-anak hendaknya menggunakan media pendidikan. Media pendidikan dilihat dari jenisnya dibagi menjadi (1) Media Auditif adalah media yang hanya mengandalkan kemampuan suara saja, seperti radio, cassette recorder, piringan hitam. (2) Media Visual, adalah media yang hanya mengandalkan indra pengelihatan. Media visual ini ada yang menampilkan gambar diam seperti film strip (film rangkai), slides (film bingkai), foto, gambar atau lukisan, cetakan. Adapun pula media visual menampilkan gambar atau simbol yang bergerak seperti film bisu, film kartun. (3) Media audio visual adalah media yang mempunyai unsur suara dan unsur gambar (Mubarak et al., 2007).

Hasil penelitian Siwi (2014) menunjukkan bahwa ada peningkatan pengetahuan dalam pemilihan jajanan sehat sebelum dan sesudah intervensi pada kelompok perlakuan. Sebelum diberikan intervensi ada 13 anak (65\%) yang memiliki pengetahuan kurang. Setelah diberikan intervensi anak yang memiliki pengetahuan baik meningkat menjadi 11 anak (55\%). Siswa mengalami peningkatan pengetahuan dalam pemilihan jajanan sehat dimana pada pre test (rata-rata 5,45; standar deviasi 0,887) menjadi post test (rata-rata 7,45; standar deviasi 1,432). Sebelum diberikan pendidikan kesehatan dengan media audio visual mayoritas responden memiliki sikap negatif. Responden belum memiliki sikap yang positif dalam memilih jajanan sehat, sikap siswa tentang ciri-ciri jajanan sehat, sikap siswa tentang pengaruh positif dan negatif jajanan, sikap siswa tentang sanitasi dan keamanan jajanan, sikap siswa tentang penyakit bawaan makanan. Setelah diberikan pendidikan kesehatan dengan media audio visual, terjadi perubahan sikap sehingga mayoritas responden memiliki sikap positif. Data ini diperkuat oleh hasil analisis statistik menggunakan wilcoxon signed rank test yang menunjukkan adanya perbedaan yang signifikan dengan nilai $\mathrm{p}=0,005$ yang artinya ada pengaruh media audio visual terhadap sikap dalam pemilihan jajanan sehat. Dapat disimpulkan bahwa pendidikan kesehatan menggunakan media audio visual efektif untuk meningkatkan pengetahuan dan tindakan camilan sehat anak di usia sekolah.

Dari hasil penelitian Pratiwi (2015) tentang pendidikan gizi tentang pengetahuan pemilihan jajanan sehat antara metode ceramah dan metode komik yaitu terdapat peningkatan pengetahuan yang signifikan pada dua kelompok yang diberi pendidikan gizi tentang jajanan sehat dengan metode ceramah dan komik $(\mathrm{p}<0,05)$. Dapat disimpulkan bahwa terdapat perbedaan antara tingkat pengetahuan sebelum dan sesudah pemberian pendidikan gizi pada dua kelompok dengan metode ceramah dan komik.

Hasil penelitian Rosyidah (2015) menyebutkan bahwa pemilihan makanan jajanan merupakan sebagai wujud dari perilaku, faktor yang mempengaruhi pemilihan makanan jajanan dibagi menjadi tiga kelompok yaitu faktor terkait makanan, faktor personal dan faktor sosial ekonomi dalam konteks pemilihan makanan. Faktor yang termasuk terkait makanan yaitu kandungan zat gizi serta komponen fisik dan kimia makanan. Faktor 
personal meliputi persepsi sensori seperti aroma, rasa, dan tekstur. Sedangkan faktor sosial ekonomi meliputi harga, merk, ketersediaan, pengaruh teman sebaya, serta budaya. Namun menurut penelitian Ariandani (2011) faktor lain yang berhubungan dengan pemilihan makanan jajanan yaitu membawa bekal makanan. Hal ini diperkuat dengan hasil analisis dengan uji Anova yang menunjukkan bahwa adanya hubungan yang bermakna mengenai frekuensi membawa bekal makanan dengan pemilihan makanan jajanan $(\rho=0,009)$. Sehingga semakin sering frekuensi membawa bekal makanan sekolah maka pemilihan makanan jajanan semakin baik

Menurut hasil penelitian Iklimah (2017) meyebutkan bahwa pemilihan makanan jajanan terkait faktor personal menyebutkan bahwa sebanyak 64,5\% dari responden mempunyai kebiasaan pemilihan jajanan yang tidak baik terkait dengan faktor personal. Sub indikator yang termasuk ke dalam faktor personal diantaranya yaitu pemilihan jajanan terkait rasa (flavor) dan aroma \& tekstur. Hasil pengumpulan data pemilihan jajanan terkait rasa didapatkan hasil bahwa sebanyak 93,6\% dari responden yaitu memilih jajanan yang tidak baik yaitu anak cenderung memilih jenis makanan yang mengandung vetsin berlebihan yang menimbulkan rasa sangat gurih dan anak juga memilih makanan pedas yang mengandung saos sambal yang berlebihan, sedangkan efek samping dari penggunaan veksin dan saos sambal yang berlebihan akan menyebabkan kerusakan pada organ pencernaan. Anak sekolah dasar menganggap rasa lebih penting daripada kandungan gizi dalam membeli jajanan.

Penelitian yang dilakukan Iklimah (2017) juga menyebutkan pemilihan makanan jajanan terkait faktor sosial-ekonomi mendapatkan hasil bahwa sebanyak 55,4\% dari responden memilih jajanan dengan tidak baik. Harga untuk $89,1 \%$ responden menjadi salah satu informasi penting untuk memilih suatu jajanan yaitu anak akan melihat atau menanyakan harga sebuah makanan jajanan kepada penjual makanan untuk melihat apakah harga makanan yang akan mereka beli sesuai dengan porsi makanan tersebut atau tidak. Tetapi Hasil observasi yang dilakukan selama tiga hari terkait rata -rata uang saku yang diterima responden mendapatkan hasil bahwa uang saku yang didapatkan responden setiap harinya yaitu Rp.5000 dan sebanyak 80,5\% dari responden selalu menghabiskan uang sakunya untuk jajan di sekolah. Hal ini menunjukkan potensi daya beli anak yang cukup tinggi. Sementara di sekitar mereka banyak terpapar oleh makanan jajanan kaki lima yang sebagian besar kurang sehat dan tidak aman dikonsumsi. Maka dari itu Orang tua bertanggung jawab atas kegiatan anak sebagai konsumen di sekolah, salah satunya melalui pemberian uang saku.

Hasil penelitian Maulana et al., (2012) menunjukkan bahwa perilaku anak mengenai pemilihan makanan jajanan mempunyai perilaku yang kurang. Hasil penelitian tersebut menunjukkan bahwa sikap anak yang positif lebih banyak yang berperilaku tidak baik. Meskipun dari hasil penelitian diketahui bahwa dari 82 responden terdapat $57 \%$ responden selalu sarapan di rumah sebelum berangkat ke sekolah namun hal tersebut tidak dapat menjamin bahwa mereka akan mengurangi jajan di sekolah. Hal ini dapat dilihat dari 82 responden terdapat $95,1 \%$ diantaranya sering jajan di sekolah.

Hasil penelitian Sukma (2014) menyebutkan Pengetahuan sangat berpengaruh terhadap pemilihan makanan jajanan. Pengetahuan dapat diperoleh baik secara internal maupun eksternal. Untuk pengetahuan secara internal yaitu pengetahuan yang berasal dari dirinya sendiri berdasarkan pengalaman hidup sedangkan secara eksternal yaitu pengetahuan yang berasal dari orang lain sehingga pengetahuan tentang makanan 
jajanan bertambah. Pengetahuan yang baik diharapkan mempengaruhi konsumsi makanan yang baik sehingga dapat menuju status gizi yang baik pula.

\section{METODE PENELITIAN}

Jenis penelitian yang digunakan adalah eksperimen (quasi experimental design) dengan rancangan nonequivalent control group design, dimana rancangan ini sangat baik digunakan untuk evaluasi program pendidikan kesehatan. Penelitian ini bertujuan untuk mengukur prilaku konsumsi makanan jajanan murid sekolah dasar sebelum dan sesudah pemberian penyuluhan dengan metode audio visual.

Penelitian ini dilaksanakan di Sekolah Dasar Negeri 52 Kota Bengkulu, waktu penelitian dilaksanakan pada 25 Juni - 25 Juli 2018. Populasi dalam penelitian ini adalah seluruh siswa kelas V (lima) Sekolah Dasar Negeri 52 Kota Bengkulu tahun 2017. Sampel pada penelitian ini Dimana terbagi menjadi 46 orang Analisis digunakan untuk melihat perbedaan rata-rata masing-masing pada kelompok yang sama. Analisis yang digunakan yaitu dengan menggunakan uji beda dua mean dependen (paired sampel).

\section{HASIL PENELITIAN}

Analisis Unvariat

Tabel. 1

Pengetahuan, Sikap, dan Frekuensi Jajanan Sebelum dan Sesudah Diberi Intervensi Pendidikan Audio Visual

\begin{tabular}{lcccc}
\hline \multirow{2}{*}{$\quad$ Variabel } & \multicolumn{2}{c}{ Pre-test } & \multicolumn{2}{c}{ Post-test } \\
\cline { 2 - 5 } & $\mathrm{N}$ & $\%$ & $\mathrm{~N}$ & $\%$ \\
\hline Pengetahuan & & & & \\
- Rendah & 24 & 52,2 & 20 & 43,5 \\
- Menengah & 8 & 17,4 & 5 & 10,9 \\
- Tinggi & 14 & 30,4 & 21 & 45,7 \\
\hline Sikap & 22 & & & \\
- Mendukung & 24 & 47,8 & 26 & 56,5 \\
- Tidak mendukung & & 52,2 & 20 & 43,5 \\
\hline Frekuensi jajan & 1 & & & \\
- Sangat sering jajan (>50) & 6 & 13,0 & 4 & 8,2 \\
- Sering jajan (25-49,9) & 4 & 8,7 & 10 & 21,7 \\
- Biasa jajan (15-24,9) & 11 & 23,9 & 3 & 6,5 \\
- Kadang-kadang jajan (10-14,9) & 24 & 52,2 & 28 & 60,9 \\
- Jarang jajan (1-9,9) & & &
\end{tabular}

Dari tabel 1 diketahui bahwa pengetahuan siswa pada kelompok intervensi pada pengukuran pertama, diketahui 24 siswa $(52,2 \%)$ Sedangkan pada pengukuran kedua, diketahui 21 siswa $(45,7 \%)$ tingkat pengetahuan tinggi.

Sikap siswa pada pengkuran pertama, 24 siswa (52,2\%) sikap tidak mendukung. Sedangkan pada pengukuran kedua, 26 siswa (56,5\%) sikap mendukung. Frekuensi jajanan pada kelompok intervensi pada pengukuran pertama, diketahui 24 siswa $(52,2 \%)$ jarang jajan. Sedangkan pada pengukuran kedua, diketahui 28 siswa $(60,9 \%)$ jarang jajan. 
Tabel. 2

Perbedaan Rata-Rata Pengetahuan, Sikap, dan Frekuensi pada Kelompok Intervensi Sebelum dan Sesudah Diberi Intervensi Pendidikan Audio Visual

\begin{tabular}{clccc}
\hline No & Variabel & Mean & SD & P value \\
\hline \multirow{2}{*}{1} & Pengetahuan & & & \\
& Pre-test & 12,78 & 3,95 & 0,002 \\
& Post-test & 14,26 & 4,19 & \\
\hline \multirow{2}{*}{2} & Sikap & & & \\
& Pre-test & 72,80 & 8,62 & 0,225 \\
& Post-test & 73,91 & 8,61 & \\
\hline \multirow{2}{*}{3} & Frekuensi & & & \\
& Pre-test & 13,20 & 13,68 & 0,84 \\
& Post-test & 12,71 & 11,74 & \\
\hline
\end{tabular}

Berdasarkan tabel 2 rata-rata total pengetahuan pada kelompok intervensi pada pengukuran pertama adalah 12,78 dengan standar deviasi 3,95. Pada pengukuran kedua didapat rata-rata total pengetahuan kelompok intervensi adalah 14,26 dengan standar deviasi 4,19. Terlihat nilai mean perbedaan antara pengukuran pertama dan kedua adalah 1,47 dengan standar deviasi 2,97. Hasil uji statistik didapatkan nilai $p$-value 0,002 maka dapat disimpulkan ada perbedaan yang signifikan antara pengetahuan kelompok intervensi pengukuran pertama dan kedua.

Rata-rata total sikap pada pengukuran pertama adalah 72,80 dengan standar deviasi 8,62. Pada pengukuran kedua didapat rata-rata total sikap kelompok interpensi adalah 73,91 dengan standar deviasi 8,61. Terlihat nilai mean perbedaan antara pengukuran pertama dan kedua adalah 1,10 dengan standar deviasi 6,11. Hasil uji statistik didapatkan nilai $p$-value 0,225 maka dapat disimpulkan tidak ada perbedaan yang signifikan antara sikap kelompok interpensi pengukuran pertama dan kedua.

Rata-rata frekuensi jajan siswa perhari pada pengukuran pertama adalah 13,20 dengan standar deviasi 13,68. Pada pengukuran kedua didapat rata-rata frekuensi jajan siswa perhari kelompok intervensi adalah 12,71 dengan standar deviasi 11,74. Terlihat nilai mean perbedaan antara pengukuran pertama dan kedua adalah 0,48 dengan standar deviasi 16,29. Hasil uji statistik didapatkan nilai $p$-value 0,840 , maka dapat disimpulkan tidak ada perbedaan yang signifikan antara frekuensi jajan siswa perhari kelompok interpensi pengukuran pertama dan kedua.

\section{PEMBAHASAN}

Anak sekolah biasanya mempunyai lebih banyak aktivitas di luar rumah dan sering melupakan waktu makan sehingga mereka membeli jajanan di sekolah untuk mengganjal perut (Rakhmawati, 2009). Kebiasaan jajan ini dipengaruhi oleh faktor jenis makanan, karakteristik personal (pengetahuan tentang jajanan, kecerdasan, persepsi, dan emosi), dan faktor lingkungan (Ariandani, 2011).

Makanan jajanan memegang peranan yang cukup penting dalam memberikan asupan energi dan zat gizi lain bagi anak-anak usia sekolah. Konsumsi makanan jajanan anak sekolah perlu diperhatikan karena aktivitas anak yang tinggi. Konsumsi makanan jajanan anak diharapkan dapat memberikan kontribusi energi dan zat gizi lain yang berguna untuk pertumbuhan anak (Sutardji \& Aznar, 2007). Jajanan anak sekolah yang kurang terjamin kesehatannya dapat berpotensi menyebabkan keracunan, gangguan pencernaan dan jika berlangsung lama akan menyebabkan status gizi yang buruk (Suci, 2009). 
Makanan jajanan beresiko terhadap kesehatan karena penanganannya sering tidak higienis yang memungkinkan makanan jajanan terkontaminasi oleh mikroba beracun maupun penggunaan Bahan Tambahan Pangan (BTP) yang tidak diizinkan (Mudjajanto, 2006). Makanan jajanan mengandung banyak resiko, debu-debu dan lalat yang hinggap pada makanan yang tidak ditutupi dapat menyebabkan penyakit terutama pada sistem pencernaan. Belum lagi bila persediaan air terbatas, maka alat-alat yang digunakan seperti sendok, garpu, gelas dan piring tidak dicuci dengan bersih. Hal ini sering membuat orang yang mengkonsumsinya dapat terserang berbagai penyakit seperti disentri, tifus ataupun penyakit perut lainnya (Irianto, 2007).

Makanan jajanan sebaiknya tidak dikonsumsi pada waktu makan utama. Konsumsi jajanan dapat menjaga kecukupan energi anak sebelum waktu makan utama tiba. Namun, konsumsi jajanan yang berlebihan juga dapat menyebabkan peningkatan berat badan apabila pilihan jajanan berupa makanan yang tinggi kalori, lemak, gula, dan rendah zat gizi yang dibutuhkan oleh anak-anak. Banyak iklan makanan yang menawarkan jajanan seperti keripik, kue kering, permen, dan minuman soda yang tidak termasuk pilihan jajanan yang baik (Koukel,2009).

\section{Perbedaan Rata-rata Pengetahuan, Sikap, dan Frekuensi Siswa Sebelum dan Sesudah Diberi Perlakuan Pengetahuan Responden tentang Makanan Jajanan}

Dari hasil penelitian didapatkan perbedaan antara pengetahuan pengukuran pertama dengan kedua adalah 1,478 dengan standar deviasi 2,972. Hasil uji statistik didapatkan nilai $p$-value 0,002 menyatakan ada perbedan yang signifikan antara pengetahuan kelompok intervensi pengukuran pertama dan kedua. Hal ini sejalan dengan penelitian Hartono et al., (2015), terlihat pada kelompok ceramah menunjukkan bahwa terdapat perbedaan yang signifikan $(\mathrm{p}<0,05)$ tentang pengetahuan pemiihan jajanan sehat sebelum dan sesudah diberi pendidikan gizi dengan metode ceramah.

Hasil penelitian ini juga sejalan dengan hasil penelitian Saputri et al., (2012) yang menyimpulkan bahwa pengetahuan dalam pemilihan jajanan sehat pada siswa sekolah dasar mengalami peningkatan setelah diberikan pendidikan kesehatan, sikap dalam pemilihan-pemilihan jajanan sehat pada siswa sekolah dasar juga mengalami perubahan setelah diberikan pendidikan kesehatan.

Pada usia sekolah dasar anak gemar sekali jajan, sehingga mereka menolak untuk makan pagi di rumah dan sebagai ganti dimintanya uang untuk jajan. Saat ini beragam jenis makanan jajanan anak sekolah dasar yang dijual di lingkungan sekolah terutama di kantin. Perilaku gizi yang salah pada anak-anak perlu mendapat perhatian. Misalnya tidak sarapan pagi, jajan yang tidak sehat di sekolah, kurang mengonsumsi sayuran, buah, dan susu, terlalu banyak mengonsumsi fast food dan junk food, makanan yang mengandung bahan pengawet, pewarna, dan penambah cita rasa (Rukmana, 2013).

Menurut Khomsan (2012) tingkat pengetahuan gizi sangat berpengaruh terhadap sikap dan perilaku dalam memilih jajanan, melalui pendidikan gizi di sekolah diharapkan melalui anak sekolah yang sadar gizi, keluargapun menjadi sadar gizi yang ditandai dengan terjadinya perubahan tingkah laku dan kebiasaan makan.

Pengetahuan sebagian besar diperoleh melalui indera penglihatan (30\%) dan indera pendengaran (10\%). Media audio visual dapat meningkatkan perhatian, konsentrasi dan imajinasi anak kemudian anak tersebut diharapkan mulai belajar menerapkan hal yang dipelajari sehingga akhirnya dapat membentuk pengetahuan, sikap dan tindakan yang baik dalam pemilihan jajanan sehat. Melalui media audio visual, anak akan mengenal tentang definisi, manfaat, dampak dan ciri jajanan sehat serta cara 
memilih jajanan yang sehat. Persepsi seseorang akan timbul melalui proses mengenal atau memilih berbagai obyek yang berhubungan dengan tindakan yang akan diambil (Notoatmodjo (2007).

Keberhasilan dalam upaya promosi keamanan pangan dengan penyuluhan pada anak sekolah tidak terlepas dari pentingnya peran sebuah media. Pendidikan kesehatan melalui kegiatan penyuluhan merupakan suatu upaya bantuan yang diebrikan kepada sasaran supaya memperole konsep diri dan kepercayaan diri sendri untuk dimanfaatakn oel dirinya dalam memperbaiki tingka lakunya pada masa yang akan datang.

Edukasi gizi dapat diberikan melalui penyuluhan pemberian poster dan leaflet pada anak sekolah. Penelitian yang dilakukan oleh Nuryanto et al., (2014) menunjukkan bahwa ada perbedaan rerata persen pengetahuan anak antara sebelum dengan setelah pendidikan gizi, dimana rerata pengetahuan gizi sebelum diberi pendidikan gizi sebesar $66,5(9,3 \%)$ naik menjadi $71,6(9,6 \%)$.

Miftahusaada (2016) menyatakan ada perbedaan pengetahuan tentang makanan jajanan sebelum dan sesudah diberikan pendidikan gizi maka pendidikan gizi menggunakan media video digital bermanfaat dalam meningkatkan pengetahuan tentang pemilihan makanan jajanan pada siswa sekolah dasar.

Hasil penelitian Febriani et al., (2018) membuktikan sebelum diberikan pendidikan kesehatan lebih dari separuh $(62,5 \%)$ anak memiliki pengetahuan cukup tentang pemilihan jajan dan sesudah pendidikan kesehatan lebih dari separuh $(75,0 \%)$ anak memiliki pengetahuan baik tentang pemilihan jajan, sedangkan hasil paired t test membuktikan pendidikan kesehatan berpengaruh terhadap peningkatan pengetahuan dalam pemilihan jajan pada anak usia sekolah 7-9 tahun di SDN 02 Desa Ngantru Kecamatan Ngantang Kabupaten Malang dengan p-value $=(0,000)<(0,050)$. Berdasarkan hasil dapat dipahami pendidikan kesehatan memberi peningkatan pengetahuan pada anak tentang pemilihan jajan sehingga menimbulkan perilaku sehat yang dapat meningkatkan derajat kesehatan anak.

\section{Sikap Responden tentang Makanan Jajanan}

Dari hasil penelitian didapatkan perbedaan antara sikap pengukuran pertama dan kedua adalah 1,109 dengan standar deviasi 6,118. Hasil uji statistik didapatkan nilai $p$ value 0,225 menyatakan tidak ada perbedaan antara sikap sebelum dan sesudah diberi intervensi. Hal ini sejalan dengan penelitian Ismail \& Ansharullah (2018) menyebutkan bahwa hasil yang didapatkan untuk sikap anak tentang jajanan makanan sebelum dan sesudah penyuluhan tidak berbeda nyata. Kenaikan yang tidak terlalu besar ini diduga sikap tidak bisa diubah secara cepat tetapi harus melalui tahap dan proses, serta dukungan orang tua.

Dilihat dari hasil analisis univariat didapatkan perbedaan sikap siswa sebelum dan sesudah yaitu sikap siswa mendukung dari 19,0\% menjadi 22,4\%. Hal ini menunjukkan ada perubahan sikap antara sebelum dan sesudah, akan tetapi perubahan tersebut tidak signifikan.

Hasil penelitian ini sejalan dengan penelitian Pakhri (2014) yang menyatakan praktek siswa Sekolah Dasar tentang konsumsi jajanan yang sehat pada SDN Baddoka Kecamatan Biringkanaya Kota Makassar masih kurang terlihat dari hasil penelitian dimana dari 119 orang sebagian besar yaitu sebanyak $58.0 \%$ memiliki praktek yang kurang. 
Faktor dukungan (support) dari pihak lain dapat mendukung perwujudan suatu tindakan dalam hal ini pemilihan jajanan. Karakteristik anak sekola dasar yaitu suka meniru orang-orang disekitarnya termasuk orang tua, guru, dan teman sebaya. Perilaku yang kerap muncul adalah meniru teman sebayanya meskipun tidak sesuai dengan dirinya. Anak sekolah dasar menganggap rasa lebih penting dbanding kandungan gizi dalam membeli jajanan dan mereka lebih sering membeli jajanan manis.

Sikap seorang anak merupakan komponen penting yang berpengaruh dalam memilih makanan jajanan. Sikap positif anak terhadap kesehatan kemungkinan tidak berdampak pada perilaku anak menjadi positif, namun sikap yang negatif terhadap kesehatan hampir pasti berdampak pada perilakunya (Notoatmodjo, 2012).

Maduretno (2015) menyatakan bahwa penggunaan metode ceramah hanya dapat meningkatkan niat dan siswa belum mengaplikasikan dalam praktik memilih pangan jajanan. Seseorang yang berpengetahuan baik tidak menjamin akan mempunyai sikap yang positif. Karena seseorang dalam menentukan sikap yang utuh selain ditentukan oleh pengetahuan, juga dipengaruhi oleh pikiran, keyakinan dan emosi yang memegang peranan penting (Notoatmodjo, 2007).

\section{Frekuensi Makanan Jajanan Siswa di Sekolah}

Dari hasil penelitian didapatkan perbedaan antara frekuensi jajanan siswa pengukuran pertama dan kedua adalah 0,487 dengan standar deviasi 16,299. Hasil uji statisik didapatkan nilai $p$-value 0.840 menyatakaan tidak ada perbedaan frekuensi jajan siswa sebelum dan sesudah diberi pendidikan kesehatan. Hal ini tidak sejalan dengan penelitian Ismail \& Ansharullah (2018) menyebukan nilai $(\mathrm{p}<0,05)$ itu artinmya ada perbedaan antara perilaku sebelum dan sesudah diberikan penyuluhan.

Dilihat dari hasil uji statistik terlihat tidak memiliki perubahan yang signifikan. Pendidikan kesehatan dengan metode audio visual belum cukup efektif untuk merubah kebiasaan siswa menkonsumsi jajanan di sekolah. Hal ini dikarenakan masih banyak faktor-faktor yang mempengaruhi kebiasaan jajan siswa disekolah. Menurut Rahman et al., (2016) faktor yang berhubungan dengan perilaku konsumsi makanan yaitu pendapatan orang tua, dan teman sebaya.

Tidak hanya itu kebijakan di sekolah juga dapat mempengaruhi kebiasan jajanan di sekolah, apabila sekolah membuat peraturan tidak boleh berjualan di sekitar lingkungan sekolah dan menyedikan kantin sekolah yang sehat, hal ini dapat menekan kebiasaan anak untuk jajan sembarangan.

Waktu yang dimiliki oleh anak usia sekolah dasar dihabiskan di luar rumah baik di sekolah maupun di tempat bermain. Hal ini mempengaruhi kebiasaan makan. Pada umumnya saat anak lapar, anak lebih suka jajan dibandingkan dengan makan utama. Makanan jajanan memberikan rata-rata kontribusi energi pada anak sekolah dasar (SD) sebesar 10-20\% terhadap AKG (Angka Kecukupan Gizi). Terdapat hubungan positif antara kontribusi energi makanan jajanan dengan tingkat kecukupan energi pada anak SD (Sulistyanto \& Sulchan 2010). Hal tersebut dapat diartikan bahwa semakin banyak anak jajan, maka tingkat kecukupan energi anak juga semakin tinggi (Sulistyanto \& Sulchan 2010). Kebiasaan jajan ini dipengaruhi oleh faktor jenis makanan, karakteristik personal (pengetahuan tentang jajanan, kecerdasan, persepsi, dan emosi), dan faktor lingkungan (Ariandani, 2011).

Febry (2006) mengamati mengapa anak-anak sekolah senang mengkonsumsi makanan jajanan, alasan tersebut diantaranya anak sekolah tidak sempat makan pagi di rumah, keadaan ini berkaitan dengan kesibukan ibu yang tidak sempat menyediakan 
makan pagi ataupun karena jarak sekolah yang jauh dari rumah atau mereka tergesagesa berangkat ke sekolah, krena alasan psikologis pada anak, jika anak tidak jajan di sekolah, anak ini merasa tidak punya kawan dan merasa malu. Dengan demikian tingginya frekuensi jajan pada anak ini juga disebabkan ibu yang sudah menyediakan sarapan pagi, namun anak tidak tertarik untuk sarapan pagi di rumah dan memilih jajan di sekolah.

Frekuensi jajan kategori tinggi pada anak 32.2\% terjadi karena anak tidak mau untuk sarapan pagi. Anak lebih menyukai makanan yang lebih praktis seperti makanan ringan seperti makanan chiki, ataupun wafer yang juga mengandung rasa manis. Frekuensi jajan kategori rendah pada anak 30,5\% menunjukkan bahwa responden mendidik anak dengan membekali makanan yang dibawa dari rumah. Jenis makanan yang dibawa adalah nasi dengan lauk telur, roti tawar dengan keju ataupun makanan yang terbuat dari bahan singkong yang sedikit mengandung gula. Ibu mengambil tindakan ini didasarkan bahwa ibu melatih anak untuk tidak membiasakan diri selalu jajan. Alasan lain adalah bahwa ibu berusaha menghindari jajanan yang manis karena kondisi gigi anak sudah mulai karies dan diharapkan gigi tidak semakin rusak seperti gigi berlubang. Apabila anak suka jajan makanan yang manis, ibu mengkhawatirkan anaknya akan sakit gigi dan akhirnya tidak dapat mengikuti kegiatan sekolah (Anugrah \& Ariya, 2012)

Besarnya uang saku yang diberikan kepada anak mempengaruhi seberapa sering anak jajan. Sebuah penelitian menunjukkan bahwa semakin besar uang saku yang diberikan maka frekuensi jajan akan semakin sering. Semakin tinggi uang saku untuk membeli jajanan maka jumlah jenis jajanan yang dibeli akan semakin banyak. (Rosyidah \& Andrias, 2013). Tidak ada hubungan yang signifikan antara pemberian uang saku dengan perilaku jajan sembarangan, dengan nilai signifikan (p) sebesar 0,246 (Gusani \& Ade, 2011).

\section{SIMPULAN}

Ada perbedaan rata-rata pengetahuan sebelum dan sesudah diberikan pendidikan audio visual di Sekolah Dasar Negeri 52 Kota Bengkulu. Tidak ada perbedaan rata-rata sikap dan frekuensi konsumsi jajanan sebelum dan setelah diberikan pendidikan audio visual di Kota Bengkulu.

\section{SARAN}

\section{Bagi Anak Sekolah}

Membiasakan sarapan pagi sebelum berangkat ke sekolah dengan jenis makanan yang sehat dan bergizi. Bagi siswa yang tidak sempat sarapan sebaiknya membawa bekal dari rumah untuk mengisi perut ketika disekolah. Sehingga uang jajan yang mereka miliki tidak dihabiskan sepenuhnya untuk jajan tetapi bisa digunakan untuk hal yang bermanfaat seperti menabung.

\section{Bagi Sekolah}

Mengadakan pengawasan jenis makanan jajanan mengenai keamanan jajanan yang ada di lingkungan sekolah maupun disekitar sekolah secara rutin (minimal satu bulan sekali) supaya siswa terhindar dari sakit yang disebabkan oleh jajanan. Menambahkan materi pembelajaran mengenai jajanan yang sehat. 


\section{Bagi Peneliti Lain}

Kelemahan penelitian ini yaitu siswa tampak bosan dengan video yang diputarkan berulang-ulang, bagi peneliti lain hendaknya memperbanyak video-video yang akan diputar, minimal setiap pertemuan hendaknya video yang diputar berbeda-beda, supaya dapat menarik perhatian anak-anak.

Dikarenakan keterbatasan waktu penelitian, masih banyak variabel-variabel yang belum sempat diteliti oleh peneliti. Apabila peneliti lain tertarik meneliti tentang frekuensi jajanan pada anak sebaiknya meneliti tentang hubungan pengetahuan terhadap frekuensi jajan, hubungan sikap terhadap frekuensi jajan, faktor- faktor pemilihan jajanan.

\section{DAFTAR PUSTAKA}

Amourisva, S. A. (2016). Kontradiksi Kebiasaan Jajan pada Anak Sekolah Dasar. Jurnal Majority, $\quad 4(8), \quad$ 143-146. https://juke.kedokteran.unila.ac.id/index.php/majority/article/view/1489

Anugrah, S., \& Ariya, A. (2012). Hubungan Frekuensi Konsumsi Makanan Jajanan Anak terhadap Kejadian Karies Gigi di Tk Aisyiyah Kateguhan Sawit Boyolali. Universitas Muhammadiyah Surakarta

Ariandani, A. B. (2011). Faktor yang Berhubungan dengan Pemilihan Makanan Jajanan pada Anak Sekolah Dasar. Artikel Penelitian Program Studi Ilmu Gizi, Universitas Diponegoro

Badan POM. (2014). Kampanye Pangan Jajanan Anak Sekolah

Febriani, K., Candrawati, E., \& Putri, R. M. (2018). Pengaruh Pendidikan Kesehatan terhadap Peningkatan Pengetahun dalam Pemilihan Jajan pada Anak Sekolah 7-9 Tahun Desa Ngantru Kecamatan Ngantang Kabupaten Malang. Nursing News, 3(1), 481-491. https://publikasi.unitri.ac.id/index.php/fikes/article/view/821

Febry, F. (2006). Penentuan Kombinasi Makanan Jajanan Tradisional Harapan untuk Memenuhi Kecukupan Energi dan Protein Anak Sekolah Dasar di Kota palembang. Universitas Diponegoro

Gusani, N. Y., \& Ade, A. (2011). Hubungan Faktor-Faktor yang Mempengaruhi Jajan pada Anak SD Kelas I dan II dengan Perilaku Jajan Sembarangan di SD Negeri Cokrokusuman Kecamatan Jetis Yogyakarta. Sekolah Tinggi Ilmu Kesehatan 'Aisyiyah Yogyakarta. Naskah Publikasi

Hartono, N. P., Wilujeng, C. S., \& Andarini S. (2015). Pendidikan Gizi tentang Pengetahuan Pemilihan Jajanan sehat antara Metode Ceramah dengan Metode Poster. Indonesia Journal of Human Nutrition, 2(2), 76-84

Iklimah, N. (2017). Gambaran Pemilihan Makanan Jajanan pada Anak Usia Sekolah Dasar. Jurnal Keperawatan BSI, 5(1), 8-17

Irianto, K. (2007). Gizi dan Pola Hidup Sehat. Bandung: CV. Yrama Widya

Ismail, I., \& Ansharullah, A. (2018). Perbedaan antara Pengetahuan, Sikap dan Perilaku Anak tentang Konsumsi Jajanan Sehat (Sebelum dan Sesudah Penyuluhan) di SD Negeri 4 Poasia Kecamatan Kambu Kota Kendari. Jurnal Sains dan Teknologi Pangan, 3(1), 1036-1051

Khomsan, A. (2012). Pangan dan Gizi untuk Kesehatan. Jakarta: Rajawali Sport

Koukel, S. (2009). Choosing Healthy Snacks for Children . Extension Faculty Health, Home and Family Development University of Alaska Fairbanks. (online) (http //:www.uaf.edu) 
Kristianto, Y., Riyadi B.D., Mustafa A. (2013). Faktor Determinan Pemilihan Makanan Jajanan pada Siswa Sekolah dasar. Jurnal Kesehatan Masarakat Nasional, 7 (11): 489-494

Maduretno, I. S. (2015). Niat dan Perilaku Pemilihan Jajanan Anak Sekolah yang Mendapat Pendidikan Gizi Metode Ceramah dan TGT. Indonesian Journal of Human Nutrition, 2

Maulana, L. O . A., Sirajuddin, S., \& Najamuddin, U. (2012). Gambaran Pengetahuan, Sikap dan Tindakan terhadap Status Gizi Siswa SD INPRES 2 Pannampu : Makasar. Jurnal Gizi Program Studi Ilmu Gizi

Miftahusaadah, M. (2016). Pengaruh Pendidikan tentang Makanan Jajanan Menggunakan Media Video Digital terhadap Pengetahuan Siswa di SDN 01 Gayamdompo Kecamatan Karanganyar Kabupaten Karanganyar. Universitas Muhammadiyah Surakarta

Mubarak, W. I., Chayatin, N., Rozikin, K., \& Supradi, S. (2007). Promosi Kesehatan. Yogyakarta: Graha Ilmu

Mudjajanto, E. S. (2006). Keamanan Makanan Jajanan Tradisional. Jakarta: Kompas

Notoatmodjo, S. (2007). Promosi Kesehatan dan Ilmu Perilaku. Jakarta: Rineka Cipta

Notoatmodjo, S. (2012). Ilmu Perilaku Kesehatan. Jakarta: PT. Rineka Cipta

Nuryanto, N., Pramono, A., Puruhita, N., \& Muis, S. F. (2014). Pengaruh Pendidikan Gizi terhadap Pengetahuan dan Sikap tentang Gizi Anak Sekolah Dasar. Jurnal Gizi Indonesia, 3(1), 121-125. https://undip.ac.id/index.php/jgi/article/view/8751

Pakhri. A. (2014). Pengetahuan dan Kebiasaan Konsumsi Makanan Jajanan pada Anak SDN Baddoka Makasar. Politeknik Kesehatan Kemenkes: Media Gizi Pangan, $X \operatorname{VIII}(2), 47-51$

Pratiwi, P. (2015). Pendidikan Gizi tentang Pengetahuan Pemilihan Jajanan Sehat antara Metode Ceramah dan Metode Komik. Indonesian Journal of Human Nutrition, 2(2), 9-17

Rahman, N., Dewi, N. U., \& Armawaty, F. (2016). Faktor-Faktor yang Berhubungan dengan Perilaku Makan pada Remaja SMA Negeri 1 Palu. Jurnal Preventif, 7(1), 1- 64. http://jurnal.untad.ac.id/jurnal/index.php/Preventif/article/view/5818

Rakhmawati, L. 2009. Kontribusi Makanan di Sekolah dan Tingkat Kecukupan Energi dan Zat Gizi Pada Anak Usia Sekolah Dasar di Kota Bogor. Institut Pertanian Bogor. http://repository.ipb.ac.id/handle/123456789/12270

Rosyidah, C. (2015). Hubungan antara Tingkat Pengetahuan dan Perilaku anak Sekolah Dasar Mengenai Pemilihan Makanan Jajanan dengan Status Gizi di SD Negeri Kudu 02 Kecamatan Baki Kabupaten Sukoharjo. Jurnal Prodi Ilmu gizi Universitas Muhammadiyah Surakarta

Rosyidah, Z., \& Andrias, D. R. (2013). Jumlah Uang Saku dan Kebiasaan Melewatkan Sarapan Berhubungan dengan Status Gizi Lebih Anak Sekolah Dasar. 10(1), 1-6

Rukmana, N. C. (2013). Hubungan Pola Konsumsi Makanan Jajanan dengan Status Kesehatan Anak Usia Sekolah di SDN Ketintang I Surabaya. Ejournal Boga, II(1), 183-189

Safriana, S. (2012). Perilaku Memilih Jajanan pada Siswa Sekolah Dasar di SDN Gatot Kecamatan Darul Imarah Kabupaten Aceh Besar Tahun 2012. Universitas Indonesia

Saputri, L., Kristiawati, K., \& Krisnana, I.(2012). Peningkatan Pengetahuan dan Sikap dalam Pemilihan Jajanan Sehat Menggunakan Alat Permainan Edukatif Ular Tangga. Universitas Airlangga Surabaya 
Siwi, L. R. (2014). Meningkatkan Perilaku Konsumsi Jajanan Sehat pada Anak Sekola melalui Media Audio Visual. Jurnal Pediomaternal, 3(1), 1-8

Suci, E. S. T. (2009). Gambaran Perilaku Jajan Murid Sekolah Dasar di Jakarta. Psikobuana, Jakarta, 1(1), 29-38

Sukma, D. C. (2014). Hubungan Pengetahuan dan Sikap dalam Memilih Makanan Jajanan dengan Obesitas pada Remaja di SMP Negeri 2 Brebes. Jurnal of Nutrition College, 3(4), 862-870

Sulistyanto, J., \& Sulchan, M. (2010). Kontribusi Makanan Jajanan terhadap Tingkat Kecukupan Energi dan Protein serta Status Gizi dalam Kaitannya dengan Prestasi Belajar. Media Medika Muda, (4), 31-38

Sutardji, S., \& Azinar, M. (2007). Tingkat Konsumsi Energi dan Konsumsi Protein serta Hubungannya dengan Status Gizi Anak Asuh Usia 10-18 Tahun (Studi pada Penyelenggaraan Makanan di Panti Asuhan Pamardi Putra Kabupaten Demak). Jurnal Kemas, 2(2),168-173

Yasmin G., \& Madanijah, S. (2010). Perilaku Penjaja Pangan Jajanan Anak Sekolah Terkait Gizi dan Keamanan Pangan di Jakarta dan Sukabumi. Jurnal Gizi dan Pangan (Pergizi Pangan) Indonesia, 5(3), 148-157

Yuliastuti, R. (2012). Analisis Karakteristik Siswa, Karakteristik Orang Tua dan Perilaku Kosumsi Jajanan pada Siswa-Siswi SDN Rambutan 04 pagi Jakarta Timur Tahun 2012. Universitas Indonesia 